\title{
CHAPTER 57
}

THE EFFECT OF WAVE ENERGY SPECTRA ON WAVE RUN-UP

\author{
J.H. van Dorschot and $\mathrm{K}$ d'Angremond \\ Delft Hydraulics Laboratory, Delft, Netherlands.
}

\section{ABSTRACT}

Previous investigations carried out by the Delft Hydraulics laboratory have shown the necessity of applying irregular waves in studies on wave run-up. The installation of a wave generator driven by hydraulic actuators has created the possibility of producing irregular waves with arbitrary wave spectra.

Investigations performed with this type of wave generator show the influence of the shape of the energy spectrum on the wave run-up on smooth stralght slopes of $1: 4$ and 1:6. The results are compared with run-up figures derived from experiments with wand generated waves and wl th monochromatic waves.

\section{INTRODUCTION}

A seawall Is generally designed to whthstand certain wave condltions. Depending upon the clrcumstances the condltions may be a storm surge, attack by waves or a combination thereof. The present study is restricted to one aspect of the attack by waves only, 1.e. the determination of the crest helght above the still water level. An accurate assessment of the required crest level is important as the cross-sectional area of the dyke increases approximately proportional to the square of the crest height.

To determine the crest level on the basis of experiments sultable criterla have to be established with respect to run-up or overtopping. The criteria shall define elther the crest level relative to a level of wave run-up under design condictions or an acceptable amount of overtopping. Lattle is known at present about the mechanism that underlies the damage caused by wave attack on dykes. The assumption seems justified however, that overtopping is one of the major factors causing damage to the inner (grass grown) slopes. It is therefore generally accepted nowadays in the Netherlands that no overtopping 1 s allowed under design conditions. This means that the crest level should be at least at the level of wave run-up.

The prevalling windwaves are unfortunately of a statistical nature with respect to their helght and period. Consequently the wave run-up is of a statistical nature too and a distinct maximum cannot be defined. The design level for wave run-up is now adopted in the Netherlands as the level which is exceeded by $2 \%$ of the uprushing waves under design con- 
ditions. If It is expected that the inner slope of a particular dyke is more or less vulnerable to overtopping this percentage can be adapted accordlngly. Paape(Ref. 1) has shown already in 1960 that the amount of overtopping water is a parameter which is in principle more relevant to damage at the inner slope than the mu-up. However, it is still a point of Investigation and discussion whlch amount of overtopplng will inltiate damage to the inner slopes. As long as the proper relationship between damage (onset and extent) and overtopping or run-up is not known nelther of these parameters are preferable to each other.

In view of the simplicity of measuring technique, in the present study the run-up is selected as a parameter.

\section{PREVIOUS INVESTIGATIONS}

In the past extensive model investigations were carried out in several Institutes to detemine the wave run-up on smooth and rough, stralght and composite slopes. A majorlty of these tests have been carried out applyıng monochromatic waves. Though the applicability of these investigatıons was limited, their great value lies in the inslght that was obtained regarding the influence of wave steepness and waterdepth on the relative run-up. (Ref. 2 and 3 ).

On the basis of the abovementioned data Saville calculated a statistical distribution of run-up assuming a joint distribution of wave helghts and periods as descrlbed by Bretschnelder for the case of fully developed sea.

Apart from the investigatıons with regular waves, tests have been carried out applyıng wind waves, generated in a wind flume. (Ref. 1). Due to the limited fetch avalable, the wind speeds had to be exaggerated in order to generate waves of appreclable helght. This resulted in waves with a great steepness and consequently a low relative run-up.

Recently the wind flume of the Delft Hydraulics Laboratory has been equipped with new wave generating facllities and it was decided to extend the investigations of. wave run-up applying irregular waves with varlable wave spectra, in order to study the influence of the spectral form and the applicability of previous investigations and calculations.

\section{RECENT INVESTIGATIONS}

\subsection{Arrangemen of the model}

The experiments have been performed in the wind-wave flume of the Laboratory at Delft. The flume $1 \mathrm{~s} 4 \mathrm{~m}$ wlde and $1 \mathrm{~m} \mathrm{hlgh}$, and has an effective length of $55 \mathrm{~m}$. The models consisting of plywood, had stralght impermeable slopes of $1: 4$ and $1: 6$ respectively, with sufficient helght to prevent overtopping. The waterdepth in front of the model was $0,40 \mathrm{~m}$. The models had a wldth of $1 \mathrm{~m}$ each and were placed in the flume as shown on Figure 1 .

During the tests the wave motion was recorded in between the models. A continuous sampling of these records was fitted into an analogue spectrum analyser for an on-line calculation of the energy spectrum of the waves. Also the frequency distribution of wave helghts was measured directly. Apart from the on-line process, all records have been digltized and analysed afterwards on a digltal computer, in order to obtann the wave energy spectrum and from it the spectral width parameter. 


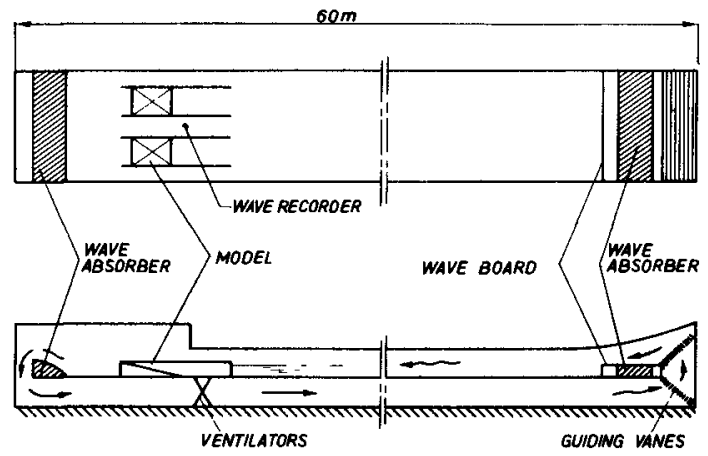

FIG I SITUATION OF MODELS

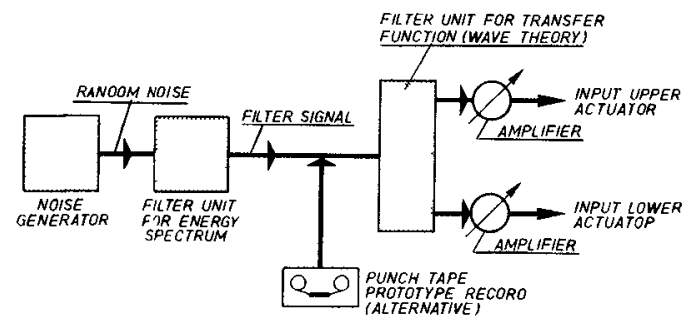

FIG 2 FORMING INPUT SIGNAL FOR THE WAVE GENERATOR

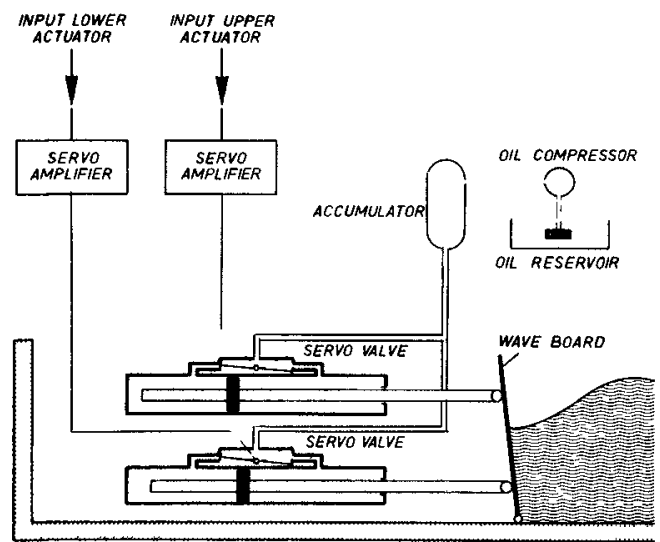

FIG 3 PRINCIPLE OF WAVE GENERATOR 
The statistical distribution of the mun-up was measured by means of an electronic multi-point gauge, which was fitted just above the slope.

\subsection{Generation of waves}

Waves were generated by a wave board. The board Is driven by two servo-controlled hydraulic actuators to produce waves whlch have the same statistical properties as the waves in nature.

$\mathrm{V}$ la a set of varlable analogue filters the slgnal of a random-nosse generator is shaped conform to the required energy spectrun. This signal is filtered again in such a way that the horizontal movements of upper and lower actuator are obtained. This transfer process is based on second order wave theory.

In addition to the artificlally generated wave profiles two punchtape records of prototype conditions in the North Sea, made avallable by the Hydraulics Division of Rijkswaterstaat, were used as an input signal for the wave board. A schematic sketch of the wave generator and a block diagram of the control procedure 1 s glven in Fig. 2 and 3 .

The adaption of the detalls of the shape of the waves is obtalned by an alr stream running over the full length of the flume.

\section{WAVE CHARACTERISTICS}

The present investigation was directed mainly on the determination of the influence of the spectral form. Therefore a varlation of the spectral form was required wh other variables kept constant. However, to extend the range of applicability of the experiments, the wave steeppness and relative waterdepth, expressed in the dimensionless terms Hs/gTc and $\mathrm{D} / \mathrm{g} \hat{T}^{2}$ have been varied too. The varlation in wave helghts and periods was limited by the required accuracy of the measurements and by the capacity of the wave generating facilities.

TABLE I

\begin{tabular}{|c|c|c|c|c|c|c|}
\hline Test & $\begin{array}{c}\hat{\mathrm{T}}^{\mathrm{x}} \\
(\mathrm{sec})\end{array}$ & $\begin{array}{c}\mathrm{Hs} \\
(\mathrm{cm})\end{array}$ & $\varepsilon_{5 \%}$ & $\begin{array}{l}\mathrm{Hs} / \mathrm{g} \hat{\mathrm{T}}^{2} \\
-10-3\end{array}$ & $\begin{array}{l}\mathrm{D} / \mathrm{g} \hat{\mathrm{T}}^{2} \\
\mathrm{x} 10^{-3}\end{array}$ & Wave generation \\
\hline $\begin{array}{ll}\mathrm{T} & 1 \\
\mathrm{~T} & 2 \\
\mathrm{~T} & 3 \\
\mathrm{~T} & 4 \\
\mathrm{~T} & 5\end{array}$ & $\begin{array}{l}0,97 \\
1,04 \\
0,95 \\
0,97 \\
0,95\end{array}$ & $\begin{array}{l}3,7 \\
4,2 \\
3,7 \\
5,6 \\
5,6\end{array}$ & $\begin{array}{l}0,38 \\
0,44 \\
0,50 \\
0,38 \\
0,50\end{array}$ & $\begin{array}{l}4,0 \\
4,0 \\
4,2 \\
6,1 \\
6,3\end{array}$ & $\begin{array}{l}43,4 \\
38,1 \\
45,1 \\
43,4 \\
45,1\end{array}$ & $\begin{array}{c}\text { random nolse } \\
\text { " } \\
" 1 \\
"\end{array}$ \\
\hline $\begin{array}{ll}\text { T } & 6 \\
\text { T } & 7 \\
\text { T } & 8 \\
6 & \text { repeated } \\
8 & \text { repeated }\end{array}$ & $\begin{array}{l}1,54 \\
1,54 \\
1,47 \\
1,54 \\
1,47\end{array}$ & $\begin{array}{r}10,2 \\
10,0 \\
10,2 \\
9,3 \\
9,7\end{array}$ & $\begin{array}{l}0,34 \\
0,45 \\
0,57 \\
0,34 \\
0,57\end{array}$ & $\begin{array}{l}4,3 \\
4,3 \\
4,8 \\
4,0 \\
4,6\end{array}$ & $\begin{array}{l}17,0 \\
17,2 \\
19,0 \\
17,0 \\
19,0\end{array}$ & $\begin{array}{l}" \\
" \\
" \\
" 1\end{array}$ \\
\hline $\begin{array}{ll}\mathrm{T} & 9 \\
\mathrm{~T} & 10 \\
\mathrm{~T} & 11\end{array}$ & $\begin{array}{l}1,64 \\
1,55 \\
1,58\end{array}$ & $\begin{array}{l}13,6 \\
13,5 \\
13,5\end{array}$ & $\begin{array}{l}0,38 \\
0,55 \\
0,59\end{array}$ & $\begin{array}{l}5,2 \\
5,7 \\
5,5\end{array}$ & $\begin{array}{l}15,3 \\
16,9 \\
16,3\end{array}$ & "1 \\
\hline $\begin{array}{l}\mathrm{T} 12 \\
\mathrm{~T} 13\end{array}$ & $\begin{array}{l}1,44 \\
1,40\end{array}$ & $\begin{array}{l}8,7 \\
7,4\end{array}$ & $\begin{array}{l}0,42 \\
0,52\end{array}$ & $\begin{array}{l}4,3 \\
3,9\end{array}$ & $\begin{array}{l}19,8 \\
21,1\end{array}$ & punch tape \\
\hline $\mathrm{T} 14$ & 0,71 & 6,0 & 0,22 & 12,2 & 81,4 & wind only \\
\hline
\end{tabular}

* $\hat{T}$ is the period in the spectrum wath maxımum energy density 


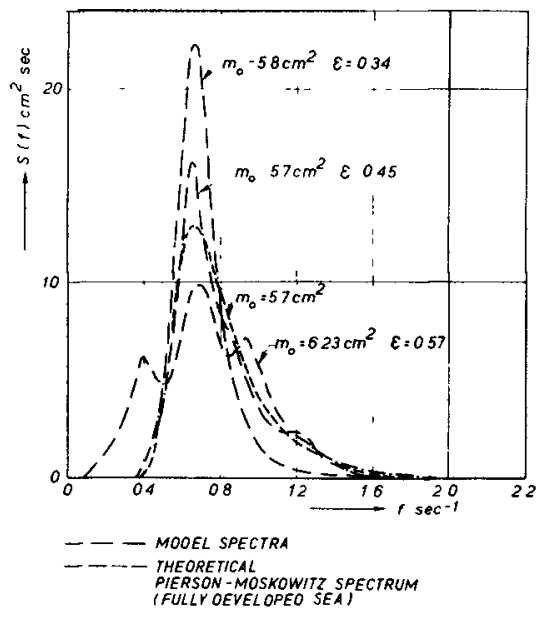

FIG 4 EXAMPLE OF APPLIEO WAVE ENERGY SPECTRA

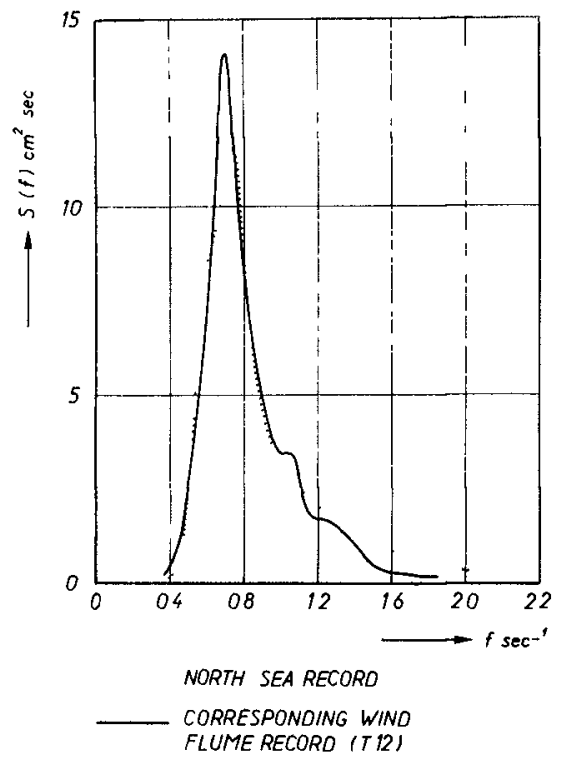

FIG 6 WAVE ENERGY SPECTRUM USING PUNCH TAPE PROTOTYPE RECORO

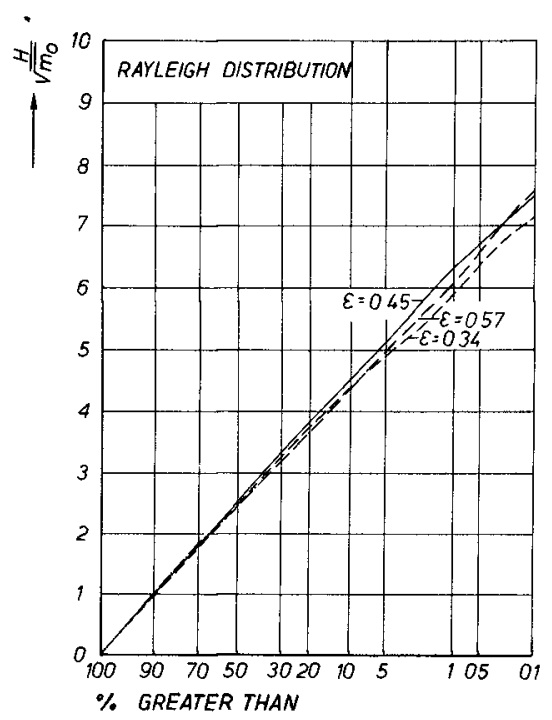

FIG 5 FREQUENCY OISTRIBUTION OF WAVE HEIGHTS

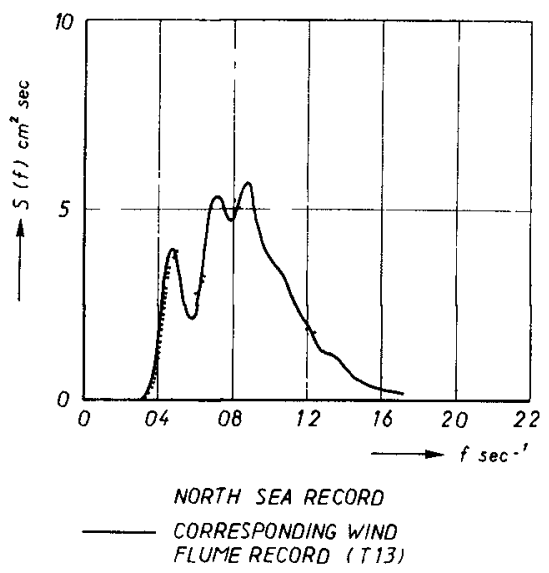

F/G 7 WAVE ENERGY SPECTRUM USING PUNCH TAPE PROTOTYPE RECORD 
The relationship between wind speed and energy spectrum of the waves as described by Plerson and Moskowltz for a fully developed sea (Ref. 5) has been used as a reference for the actually applied spectral forms and wave steepnesses. Figure 4 shows such a spectrum type for a particular wave perlod (wind speed). As the requirements for a state of full development however are restrıcted to a few cases only, wave spectra and wave steepnesses with appreciable deviations mav occur.

By varylng the relative waterdepth $\mathrm{D} / \mathrm{g} \mathrm{T}^{2}$ from $15.3 \times 10^{-3}$ to 45.1 $\times 10^{-3}$, conditions were accomplished for almost shallow water waves to almost deep water waves.

The spectral form is expressed in the relative wldth parameter $\varepsilon$. defined as follows (Ref. 6 ):

$$
\varepsilon^{2}=\frac{m_{0} m_{4}-m_{2}^{2}}{m_{0} m_{4}} \text { in which } m_{n}=\int_{0}^{\infty} s_{(w)} \cdot w \cdot{ }^{n} d w
$$

The calculation of the spectrum and $\varepsilon$ has been carried out on a digital computer using the digitızed wave records. The Nyquist frequency was $3.2 \mathrm{cps}$. The frequency interval between adjacent estimates of the spectral density $0.0533 \mathrm{cps}$. The oorrelation function was passed through a triangular screen filter. Inherent to the definltion of $\varepsilon$, the higher frequencies have an unproportional large influence on the calculated value of $\varepsilon$, whereas both the accuracy and the practical interest of this frequency range is small. Therefore the calculation of $m_{n}$ is carried out for that part of the spectrum for which the energy density $S(\omega)$ at $\omega>\hat{\omega}$ is greater than $5 \%$ of the maximum energy density $s(\hat{\omega})$. The consequences of this cut-off procedure for one special case (T13) are shown in Table II.

\section{TABLE II}

$\begin{array}{ccccccc}\text { Iimitation at } & 0 \% & 1 \% & 2 \% & 3 \% & 4 \% & 5 \% \\ \varepsilon & 0.648 & 0.599 & 0.550 & 0.533 & 0.523 & 0.518\end{array}$

From the two test runs in which the input signal consisted of a prototype wave record from the North Sea a comparison has been made between the wave spectra and wave helght distributions from the prototype and those from the wave flume. Flgures 6 and 7 show the wave spectra, Figures 8 and 9 the wave helght distributions

\section{BESULTS}

The frequency distribution curves of the run-up of all tests have been plotted on Gaussian distribution paper, like Fig. 10. Comparing sets of distribution curves, each set for wave conditions with the same significant wave helght (Hs) and period ( $\mathbb{T}$ ) but different $\varepsilon$ values, shows that there is an influence of $\varepsilon$ in that way that the "steepness" of the run-up distribution is greater for higher $\varepsilon$ values (Flg. 10).

Though only a few tests have been performed in which the waterdepth and the wave steepness have been varled independently It appeared that neither a variation in waterdepth nor a variation in wave steepness has a slgnlflcant Influence on the "steepness" of the run-up distribution curve, so all curves can adequately be characterlzed by the run-up at 


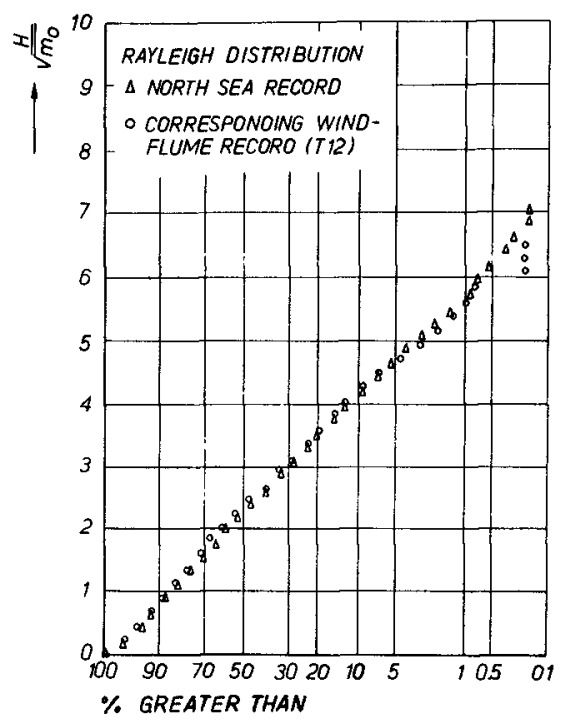

FIG 8 FREQUENCY OISTRIBUTION OF WAVE HEIGHTS USING PUNCH TAPE PROTOTYPE RECORD

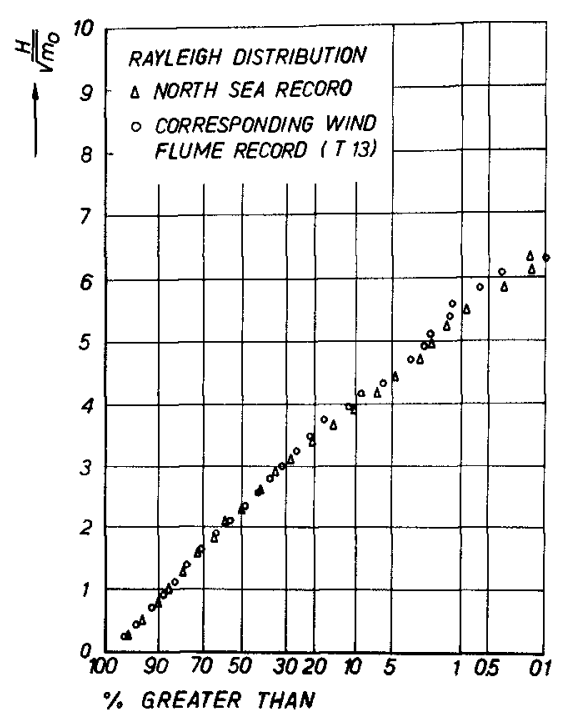

FIG 9 FREQUENCY DISTRIBUTION OF WAVE HEIGHTS USING PUNCH TAPE PROTOTYPE RECORD

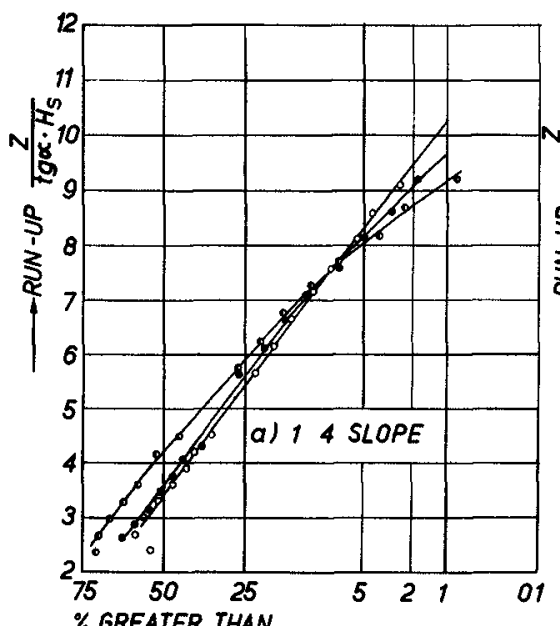

\% GREATER THAN

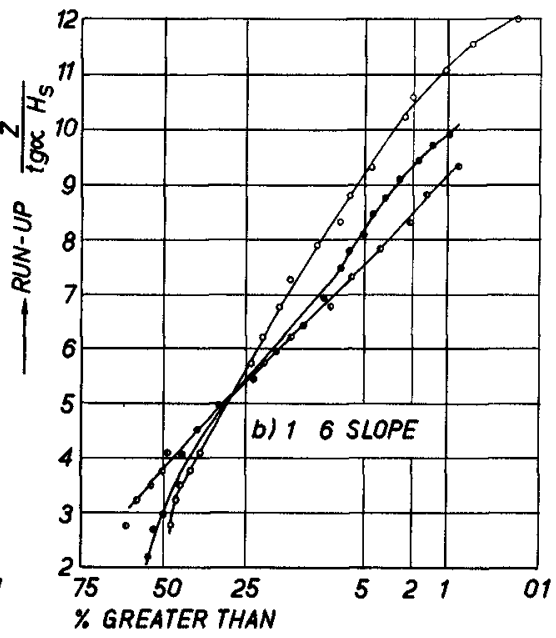

$\circ \bar{H}_{S}=102 \mathrm{~cm} \quad \hat{T}=147 \mathrm{sec} W I D E \quad \varepsilon=057$

- $\bar{H}_{S} \cdot 100 \mathrm{~cm} \quad \hat{T} \cdot 154 \mathrm{sec}$ MEDIUM $\varepsilon=045$

- $\bar{H}_{S}=102 \mathrm{~cm} \quad \hat{T}=154 \mathrm{sec}$ NARROW $\varepsilon=034$

FIG 10 FREQUENCY OF RUN-UP 
one specifıc exceedance percentage.

The mun-up distribution curve is characterized by the level of run-up surpassed by $2 \%$ of the waves $\left(z_{2}\right)$ for reasons explained in the Introduction.

In the case of monochromatic waves it 1 s known that for $\mathrm{D}<3 \mathrm{H}$ the influence of the waterdepth is perceptible. One may expect therefore that the same holds for I rregular waves, with a comparatively small $\mathrm{D} / \mathrm{H}$ ratio. Such a situation has not been investigated so far.

Hunt (Ref. 3) developed an emplrical formula for the wave run-up on smooth impermeable slopes, based on tests wh th monochromatic waves:

$$
\frac{z}{H}=\frac{\mathrm{C} \operatorname{tg} \alpha}{\sqrt{H / L_{0}}}
$$

The experiments indicate that also in the case of irregular waves the influence of the slope is well expressed by this formula as far as the differences between the slopes 1:6 and 1:4 are concerned.

Substituting the irregular wave characteristics in (1) the following expression is obtained:

$$
\mathrm{z}_{\mathrm{n}}=\frac{\mathrm{C}_{\mathrm{n}}(\varepsilon) \cdot \mathrm{Hs} \cdot \mathrm{tg} \alpha}{\sqrt{\mathrm{Hs} / \mathrm{L}}}
$$

or

$$
z_{n}=\frac{C_{n}(\varepsilon) \cdot H s \cdot \operatorname{tg} \alpha}{\sqrt{H s / g T^{2}}}
$$

The subscript $n$ denotes the frequency of exceedence. The unknown factor $C_{n}$ whlch is directly proportional to the wave run-up is not a constant as for monochromatic waves but a function of $\varepsilon$. In Fig. 11 the $\mathrm{C}_{2}$ values of all tests have been collected and expressed as a function of $\varepsilon$. Notwithstanding the scatter in the $C_{2}$ values, it is evident that $\varepsilon$ is an lmportant parameter in the run-up phenomenon in that way that a wave motion with a wider spectrum produces considerable higher muup for the smaller exceedance frequencies than a wave motion with a narrow spectrum. The $C$ values are separated for both slopes because the influence of $\varepsilon$ in the case of 1:6 slope is slightly larger than for the 1:4 slope. The scatter Is falrly small if one considers that the calculation of $\mathrm{C}_{2}$ is based on an emplrical formula derived from tests with monochromatic waves. Consequently lt seems justıfied to assume that the influence of the wave characteristics $H_{5}$ and $\hat{T}$ is well expressed in formula (3). However it should be stressed that this is valid only within the range of conditions tested.

As mentioned before two tests have been conducted with waves generated by making use of wave records from the North sea (T 12 and 13 ) The wave run-up obtalned in this way, expressed in the $\mathrm{C}_{2}$ values of formula (3), is in good agreement with the mu-up values obtained by maklng use of filtered nolse (fig. 2) as an input signal for the wave generator. See Flg. 11 .

Wind blowlng over a water surface in a wind flume has been for many years the only possibllity of simulating wind generated ocean waves in the Delft Hydraulics Laboratory, and this method is still used in many other laboratories. At the D.H.L. many tests have been performed w th 
a) 16 SLOPE

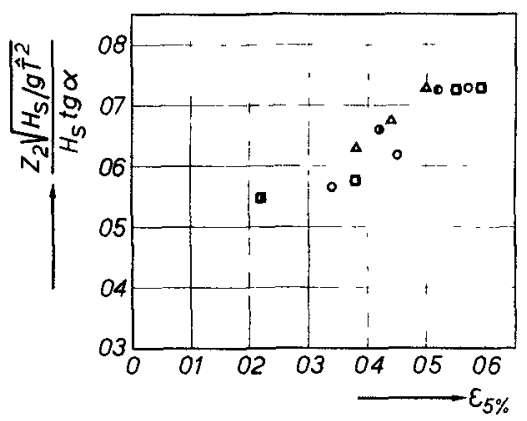

$\Delta \quad T_{1}, T_{2}, T_{3}$

$\Delta T_{4}, T_{5}$

- $T_{6}, T_{7}, T_{8}$

- $T_{6}, T_{8}$ REP b) 4 SLOPE

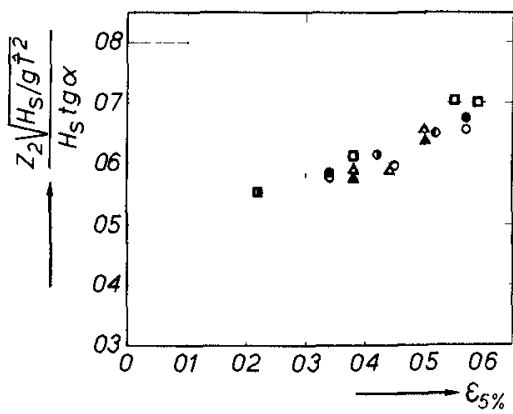

- $T_{9}, T_{10}, T_{11}$

- $T_{12}$

- $T_{13}$

- $T_{14}$

FIG 11 RELATIVE WAVE RUN-UP AS A FUNCTION OF THE SPECTRAL WIDTH $\varepsilon_{5 \%}$

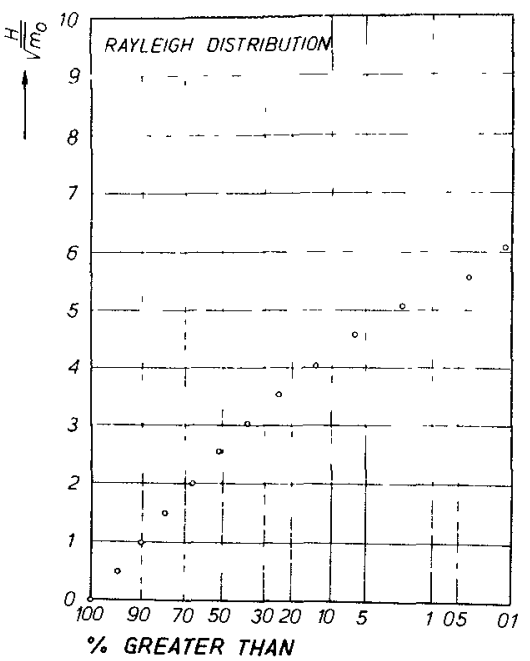

FIG 12 FREQUENCY DISTRIBUTION OF WAVE HEIGHTS FOR WINO GENERATED WAVES 
this type of wave generation (Ref. 1). However, since the fetches are mostly relatively short, the wind speed has to be exaggerated to obtain waves of sufflcient helght and consequently also the wave steepnesses are exaggerated. In view of this, one test has been carried out using wind generated waves instead of mechanlcally generated waves. (See T 14) of Table I).

The wind speed was such that a comparative wave height was obtalned in relation to former experiments. The resulting large wave steepness (Hs $/ \mathrm{gT}^{2}=12.2 \times 10^{-3}$ ) was primarly the reason for a relatrvely low run-up on the two slopes, as the run-up decreases at increasing wave steepness. Moreover the wave spectrum was extremely narrow, as may appear from the $\varepsilon$-value of only 0.22 , and the wave helght distribution was quite different from the Rayleigh distribution as opposed to all other tests. Compare Figure 5 and 12. In spite of the deviating wave characteristics however the location of the corresponding $\mathrm{C}_{2}$-values ( $T$ 14) in Figure 11 indicates that formula (3) is still applicable.

\section{ANALYSIS OF RESULTS}

To permit an estimation of the variability in irregular wave run-up without the use of faclities for irregular wave generation, Saville has proposed the following calculation of a statistical distribution of wave run-up (Ref. 4), usıng standard (monochromatıc) wave run-up curves.

The probability of a combination of a particular wave height and wave perıod. may be given as:

$$
\mathrm{p}(\mathrm{H}, \mathrm{T})=\mathrm{p}(\mathrm{H}) \cdot \mathrm{p}(\mathrm{T}),
$$

consequently assuming a zero-correlation between wave helght and wave period. The probability distrubutions used were those proposed by Bretschnelder (Ref. 7) for fully developed sea.

With the expression (4) one can obtain a joint distribution of wave steepness $\mathrm{p}\left(\mathrm{H} / \mathrm{g} \hat{\mathrm{T}}^{2}\right)$ and wave helght, and subsequently

using standard run-up curves giving the relation between relative runup and waye steepness (Ref. 2), a distrıbution of Individual relative run-up $\mathrm{p}\left(\frac{Z}{\mathrm{H}}\right)$. Multiplication of a particular mun $\frac{Z}{\mathrm{H}}$ with the associated. wave helght from the assumed joint distribution of wave helghts and periods for a particular wave condition, results in a distribution of run-up $p(z)$.

To check the applicability of this calculation and to get more insight in the influence of the spectral shape on the wave run-up a calculation as descrubed is performed for two wave conditions (a wide and narrow spectrum) for which run-up distributions have been measured (T 6 and T 8 of Table I). Instead of assuming a zero-correlation between wave helghts and periods however actual wave records of the two wave conditions have been used for the determination of the jolnt distribution $\mathrm{p}(\mathrm{H}, \mathrm{T})$. The records were analysed by hand, taking 300 successıve waves into consideration. The result is shown on Figure 13 in which every point represents a wave with both helght and period within a certain class. Following the method of Saville a distribution of run up of 300 indlvidual waves is obtalned for two different spectra and 2 different corresponding $\mathrm{H} / \mathrm{T}$ correlations. The solid lines on Figure 14 show the result of the calculation. Although this calculation is rather simplified it appears that, 

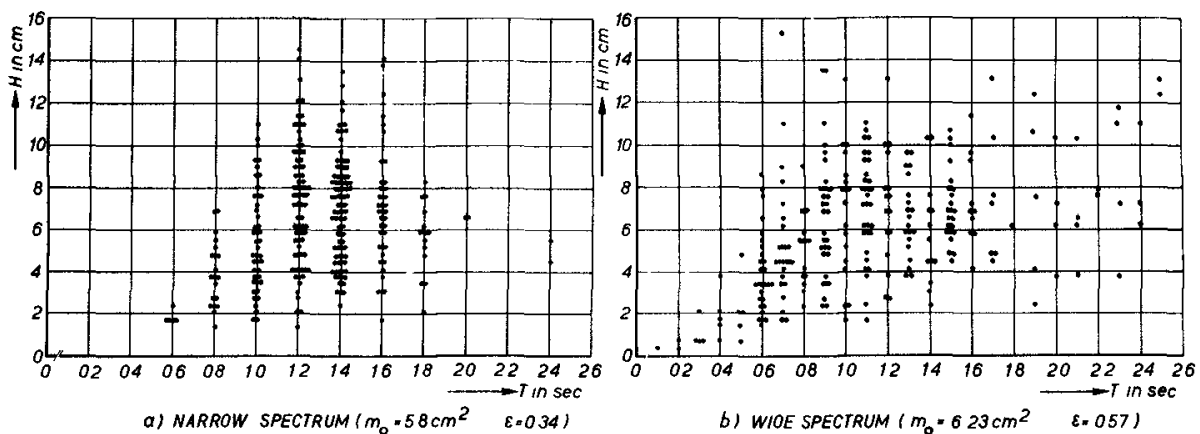

FIG 13 JOINT OISTRIBUTION OF WAVE HEIGHT AND PERIOO

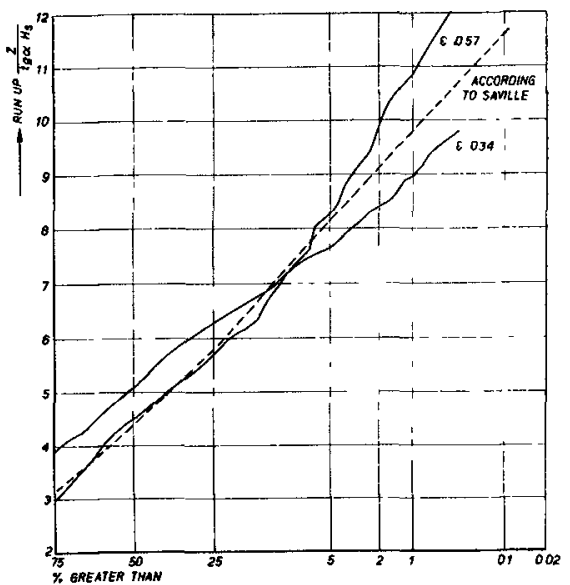

FIG 14 FREQUENCY OF RUN-UP CALCULATEO 
thanks to the fact that a large amount of waves is consldered, the obtained result is in remarkable good agreement with the recorded wave run-up for the same wave condition. Compare Figure 10 and Figure 14. The calculation shows in addition that the difference in the higher part of the run-up curve for the two wave condltions consldered was caused by the few long, low waves present in the case of a wide spectrum only (FIg. 13). This was also conflrmed by visual observation. These waves with extreme low steepness hardly break on the slope and consequently cause an unproportional hlgh run-up. The assumption of a zero-correlation between wave helght and percod according to Saville's method results in a run-up distribution (the dotted line on Figure 14) which corresponds with the measured run-up distribution for the middle one of the three spectra in Flgure 4 (the Plerson Moskowltz spectrum for fully developed sea).

Calculated and measured distributıon curves diverge at higher exceedance percentages as a result of the applied measuring technique. 


\section{CONCLUSTONS}

- The statıstical run-up distribution curves diverge at the smaller exceedance percentages for different spectral forms. Wider spectra are accompanied by higher run-up.

- Increase in wave run-up for wider spectra is caused by differences in the joint distribution of wave helghts and perıods. The distributions of wave helghts only are the same for the different spectra.

- The relationshıp $z_{n}=\frac{C_{n}(\varepsilon) \cdot H s \cdot \operatorname{tg} \alpha}{\sqrt{H s / g T^{2}}}$ gives a good approximation of the influence of wave helght, wave perlod and slope for the conditions investigated.

- Wind waves generated in the laboratory applying exaggerated wind speed, produce wave run-up which Is generally to low due to the extreme narrow wave spectrum.

$\pi$ The calculation of a statistical wave run-up distribution curve assuming a zero-correlation between wave helght and period as described by Saville agrees falrly well with the measured one for a state of fully developed sea. Taking into consideration varlations in the joint distribution of wave helghts and periods for spectra different from the spectrum of fully developed sea, a higher run-up is obtalned for wlder spectra; conversely lower run-up goes with narrower spectra.

\section{REHERENCES}

1. Paape, A., Experimental Data on the Overtopping of Seawalls by Waves; Proc. of the Seventh Conf. on Coastal Eng., 1960.

2. U.S. Army Coastal Engineering Research Center; Shore Protection Plannıng and Desıgn; Technical Report no. 4, 1966.

3. Hunt, I.A. Jr.; Design of Seawalls and Breakwaters; Proc. of the Am. Soc. of Clv. Fing., Journ. of the Waterw. and Harb. Div.; 85, 1959, no. ww 3, part I, paper 2172.

4. Saville, Th., Jr.; An Approximation of the wave Run-up Frequency Distribution; Proc. of the Elghth Conf. on Coastal Eng., Nov. 1962.

5. Plerson, J.W., Jr.; and Moskowztz, L.; A Proposed Spectral Form for Fully Developed Wind Seas Based on the Similarity Theory of S.A. Kitalgorodskı1; Journ. of Geoph. Res., 1964, Vol. 69, no. 24; Dec.

6. Kınsman, B.; Wind Waves; New Jersey, 1965.

7. Bretschneider, Ch.L.; Wave Varıability and Wave Spectra for WindGenerated Gravity Waves; Technlcal Memorandum No. 118; U.S. Army Coastal Englneering Research Center, 1959. 